Article

\title{
The Integration of 3D Modeling and Simulation to Determine the Energy Potential of Low-Temperature Geothermal Systems in the Pisa (Italy) Sedimentary Plain
}

\author{
Alessandro Sbrana ${ }^{1, *}$, Paola Marianelli ${ }^{1, *}$ (1) , Giuseppe Pasquini ${ }^{1}$, Paolo Costantini ${ }^{1}$, \\ Francesco Palmieri ${ }^{2}$ (D), Valentina Ciani ${ }^{3}$ and Michele Sbrana ${ }^{3}$ \\ 1 Dipartimento di Scienze della Terra, University of Pisa, Via S. Maria 53, 56126 Pisa, Italy; \\ giuseppe.pasquini@dst.unipi.it (G.P.); paolo.costantini@dst.unipi.it (P.C.) \\ 2 Istituto Nazionale di Oceanografia e di Geofisica Sperimentale-OGS, Borgo Grotta Gigante 42/C, \\ 34010 Sgonico (TS), Italy; fpalmieri@inogs.it \\ 3 Terra Energy, Via Lenin 132-56017 San Giuliano Terme (PI), Italy; ciani@terra-energy.it (V.C.); \\ m.sbrana@terra-energy.it (M.S.) \\ * Correspondence: alessandro.sbrana@unipi.it (A.S.); paola.marianelli@unipi.it (P.M.)
}

Received: 15 May 2018; Accepted: 14 June 2018; Published: 18 June 2018

\begin{abstract}
Shallow, low-temperature geothermal resources can significantly reduce the environmental impact of heating and cooling. Based on a replicable standard workflow for three-dimensional (3D) geothermal modeling, an approach to the assessment of geothermal energy potential is proposed and applied to the young sedimentary basin of Pisa (north Tuscany, Italy), starting from the development of a geothermal geodatabase, with collated geological, stratigraphic, hydrogeological, geophysical and thermal data. The contents of the spatial database are integrated and processed using software for geological and geothermal modeling. The models are calibrated using borehole data. Model outputs are visualized as three-dimensional reconstructions of the subsoil units, their volumes and depths, the hydrogeological framework, and the distribution of subsoil temperatures and geothermal properties. The resulting deep knowledge of subsoil geology would facilitate the deployment of geothermal heat pump technology, site selection for well doublets (for open-loop systems), or vertical heat exchangers (for closed-loop systems). The reconstructed geological-hydrogeological models and the geothermal numerical simulations performed help to define the limits of sustainable utilization of an area's geothermal potential.
\end{abstract}

Keywords: 3D modeling; 3D numerical simulation; geographic information systems (GIS) geodatabase; geothermal potential assessment; shallow geothermal

\section{Introduction}

Sustainability, including in urban areas, has become a key concern when planning for the future [1]. Increasing energy demand, the changing climate, and energy resources limitations have prompted several countries to introduce strategies to enhance energy-efficiency and production sustainability. The construction and ongoing use of the built environment are substantial contributors to growing energy demand, using from 20 to $40 \%$ of the energy consumed in developed countries and accounting for more than 30\% of total greenhouse emissions [1,2]. In Europe, the Directive on Energy Performance of Buildings [3] states that all new constructions should be "zero-energy buildings" by the end of 2020. This implies buildings that consume minimum levels of renewably sourced energy. By replacing fossil fuel sources and substantially reducing the $\mathrm{CO}_{2}$ emissions, renewable energy sources help 
mitigate global warming. Low temperature geothermal resources, as used for heating and cooling (via geothermal heat pumps [GHPs]), are one of the renewable sources that can contribute to energy efficiency and greenhouse gas reduction, while having only marginal negative environmental effects. Best practice in geothermal exploration, including quantitative assessment of geothermal plays [4], is a key step towards sustainable power generation. Multidisciplinary spatial data (including regional geological, stratigraphic, structural, geophysical and volumetric data) with temperature measurements and hydrogeological and geothermal parameters derived from wells and exploratory boreholes are essential to reliable assessment. Accurate three-dimensional modeling considering the heterogeneity of the environment requires integration of diverse data sources [5-7]. The contributing technologies include smart geographic information systems, their databases, 3D geological modeling, and 3D numerical simulation tools, which are already widely used and tested in research and the geothermal industry. GIS applications in geothermal exploration are common, especially in the planning phase for site selection [8] and for calculating and mapping the geothermal potential $[9,10]$. Papers on modeling in the geothermal domain commonly focus on data integration and elaboration, and visualization in 3D modeling platforms [11-13]. These papers highlight the importance of 3D modeling, combining multiple datasets and procedures, and thus demonstrate the value of these tools in the management of geothermal resources. The integration of 3D modeling tools with 3D geothermal reservoir simulation tools is less common, although some authors $[14,15]$ have studied both low- and high-enthalpy geothermal systems.

This paper proposes a methodology for robust 3D geological modeling and tests its application in a low-temperature environment. The model outputs are necessary for estimation of the potential for effective deployment of ground source heat pumps and to support the design of efficient low-temperature geothermal plants. Geothermal simulations, when compared with direct, spatially distributed measurements in aquifers, provide for model calibration and hence accurate geothermal project analysis.

Our case study area is the Pisa alluvial plain located north of the Tuscany (Italy) geothermal district. This area is characterized by a geothermal gradient of $50-60{ }^{\circ} \mathrm{C} \cdot \mathrm{km}^{-1}[16,17]$ and by fault-driven thermal springs. This is a typical low-temperature geothermal play, which is suitable for direct use of GHPs for heating and cooling.

\section{Methodology}

A geothermal geodatabase was designed to accommodate the assembled ArcGIS (v. 10.2, ESRI, Redlands, CA, USA) GIS data. Key data included subsoil stratigraphy, i.e., the depths and thicknesses of geological units as obtained from well-log lithology and by the interpretation of geophysical surveys for deeper units, and the subsurface aquifers, i.e., their nature (phreatic, confined, artesian), chemical composition, temperatures, and hydraulic properties (flow rates and volumes). The selected data were firstly organized in tabular format for import into the dedicated geothermal geodatabase (Figure 1).

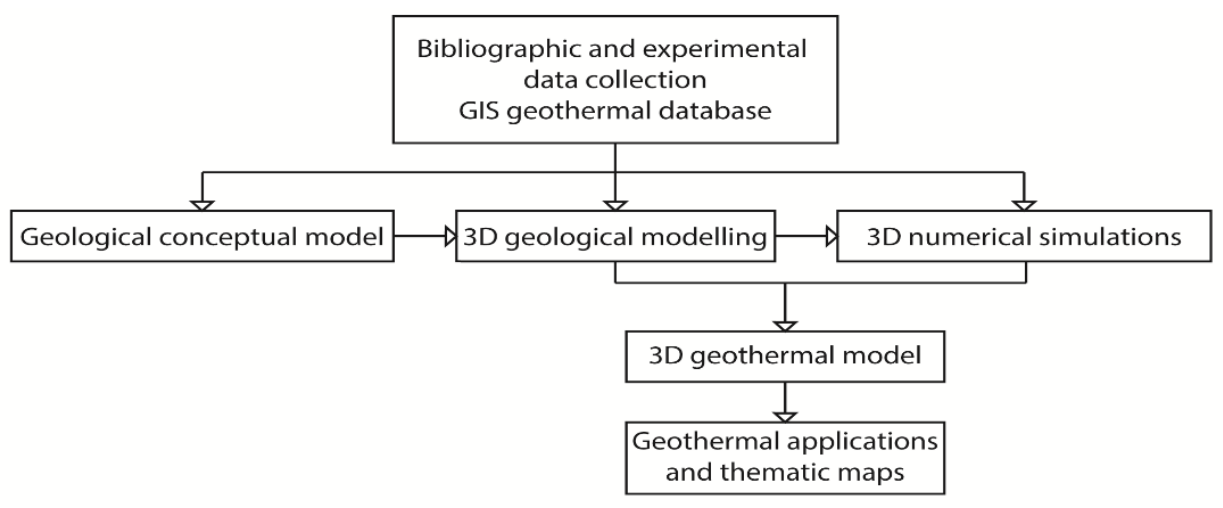

Figure 1. Proposed methodology. 
Next, a conceptual model of the subsoil was defined for the area, based on the encoded lithostratigraphic, hydrogeological and geothermal knowledge, together with the scientific and technical literature.

Subsurface modeling is normally based on interpretation of two-dimensional (2D) cross-sections, maps, well logs, and geophysical surveys. The incorporation of 3D modeling allows interpolation of the subsurface units and their features, significantly improving understanding and visualization of the subsoil geological framework. In our approach, the integration of point data, 2D cross-sections and 3D modeling was performed using the Schlumberger Petrel E and P Software Platform (v. 2016.1, Schlumberger-Software Integrated Solutions, Parma, Italy). This software is a complete application for 3D geological-geophysical modeling.

All required data were imported from the designed GIS geodatabase. Point data were converted into areal information using the Petrel "convergent interpolation algorithm", an iterative algorithm that delineates the top surfaces of the main lithological units. Each iteration of the convergent interpolation algorithm consists of three steps: (1) Refine-increase grid resolution; (2) Snap—regrid the data; and (3) Smooth-minimize curvature of the grid [18].

Starting with the upper surfaces, a 3D grid was used as the basis of a 3D geological model of the investigated area. The initial conceptual model was revised using improved 3D elaboration and visualization: For example, lithostratigraphic and well log data can suggest adjustments to the geothermal geodatabase, while the 3D reconstruction of aquifers allows the conceptual model to be further modified and improved. The refined geological conceptual model and the resultant 3D Petrel subsurface model became the framework for subsequent geothermal simulations. The top surfaces of the subsurface units, from the 3D modeling, were imported into TOUGH2 [19] through the PetraSim (version 5; Rockware Inc, Golden, CO, USA) graphical interface. TOUGH2 is a non-isothermal multiphase fluid flow simulator for modeling heat and mass transfer in geothermal systems. In this study, the EOS1 module was used. The computational approach used in TOUGH2 is based on the integral finite difference (IFD) method [20] using fully implicit time discretization. The residual form of the system of equations, considering the underground lithological setting, the heat flow dynamics, and the heat exchange and fluid mass transport laws, is solved using the Newton-Raphson iteration method [21]. Geothermal parameters, including density, porosity, permeability, heat conductivity, and specific heat (both literature-derived values and in situ measurements), were assigned as input data to subsoil units. The boundary conditions were set as for a closed system. A grid size was chosen for the calculation based on the required spatial resolution and the acceptable computational load. The simulation then modeled the steady state of the subsoil volume.

Temperature data, as measured in water, geothermal, and deep oil and gas exploratory wells, were used to check the thermal settings of the model. Several iterations were performed to obtain the best fit between measured and simulated temperature data. The distribution of output temperatures, obtained through the TOUGH2 simulation, was transferred back to the Petrel software, allowing visualization of the 3D distribution of subsoil temperatures in the aquifer or geological units (along the $X-, Y-$, or Z-axis, in 2D sections or as well logs). Further, the simulated temperatures may be integrated with temperature values measured in existing wells, giving a robust picture of the $3 \mathrm{D}$ temperature distribution in the subsoil. These temperatures were interpolated to a continuous raster surface, using an inverse distance weighted (IDW) interpolation [22]. IDW is a deterministic interpolation method that give greater weight to points closer to the unknown point that we want to estimate, than to distant ones. Cell values are averaged over the nearest data points, and the influence of distant data decreases exponentially, with the power of 2 . This process allows the production of temperature maps at different depths.

Moreover, the GIS raster calculator tool was used to generate thematic maps. It allows execution of map algebra expressions involving two or more rasters, resulting in a new raster. In this study, starting from the top surface of the lithological units (input raster) and using the "volumetric method equation" $[23,24]$, the volumes of the lithological units were determined. The outputs allow easy 
estimation and mapping of geothermal potential and other useful geothermal parameters, including temperatures and aquifer volumes.

\section{Case History}

The Pisa plain consists primarily of neoautochthonous deposits that fill a wide and deep half-graben striking NW-SE [25]. The Pleistocene evolution of the sedimentary basin has resulted in a complex stratigraphic pattern in which marine and continental sand-gravel layers alternate and interdigitate with clay layers [26] covering a bedrock formed by carbonate units pertaining to the Tuscan Nappe [27].

The generally accepted regional hydrogeological framework [28-40] is based on the so-called "confined multilayered aquifer" system [33], and is formed by two main confined aquifers, hosted in coarse sediments, sands, and gravels. These are separated by clay-rich layers or are locally connected in areas without clay units.

\subsection{Database Setting, Data Screening, Collection, and Processing}

The available data, including maps and databases of existing wells with subsoil temperatures and water composition, for the Pisa sedimentary plain were collected from diverse sources. The data were often not in digital form and varied in nature and quality. To define a trustworthy conceptual geothermal model of the area, we undertook a new hydrogeochemical survey that provided accurate contemporary information about aquifer quality and temperature distributions in the subsoil.

Direct temperature measurement in existing water wells is particularly difficult because of physical obstacles (such as well heads or submersible pumps that make it impossible to insert thermometers); however, these data are fundamental to the subsequent steps of the workflow (the thermal simulation being calibrated on measured temperatures). To resolve the problem, we selected water wells having a constrained depth of water captation (filters or slotted liners) in the multilayer aquifer. The temperature of the aquifer was recorded at the well head after the observed water temperature stabilized. This is valid, as the deviation between temperatures measured at the well head, in dynamic conditions, and direct measurements in the aquifer has been found to be less than $1 \%$.

The data storage process requires that the data are properly structured and encoded. A geothermal database was designed, organized, and implemented, and four information layers were mutually connected using a key identity field. Geographic coordinates were converted into a common reference projection, WGS_1984_UTM_Zone_32N (EPSG 32632), in the GIS [41]. The GIS also contained raster elements including geological maps, thematic maps and a digital terrain model (DTM).

\subsection{Geological Conceptual Model}

The lithostratigraphy of the shallower sedimentary sequence, to a depth of about $200 \mathrm{~m}$, was reconstructed using the borehole database (Figure 2a). This corresponded to the maximum depth reached by water wells in the area; higher depths are reached only by a few other wells (geothermal and hydrocarbon exploration). Our focus in the subsoil reconstruction, at these shallow depths, was on the geometry of sediments hosting aquifers and the impervious layers separating aquifers. The geological framework was reconstructed through several sections. Figure $2 b$ shows an example of a section traversing the graben structure.

The lithostratigraphic correlations of wells and sections allowed synthesis of the conceptual geological/hydrogeological model illustrated in Figure 3. The following units were defined:

Coastal Dune Unit (CDU): eolian and marine sand deposits. This extends from the coast to the western side of Pisa town [42]. It contains an aquifer fed by meteoric and sea water.

Recent Alluvial Cover (RAC): clays and discontinuous sand bodies, with deposits from the Arno and Serchio rivers [40]. These host small, discontinuous, phreatic, lenticular aquifers in sand.

Gravel Fans Unit (GFU): a succession of continental gravel deposits with interlayers of minor clay-rich sediments that stretch from the Monte Pisano fans to the Pisa plain [42]. This highly 
permeable unit hosts several springs $[33,43,44]$ and is a recharge area for the aquifers of the alluvial-sedimentary plain.

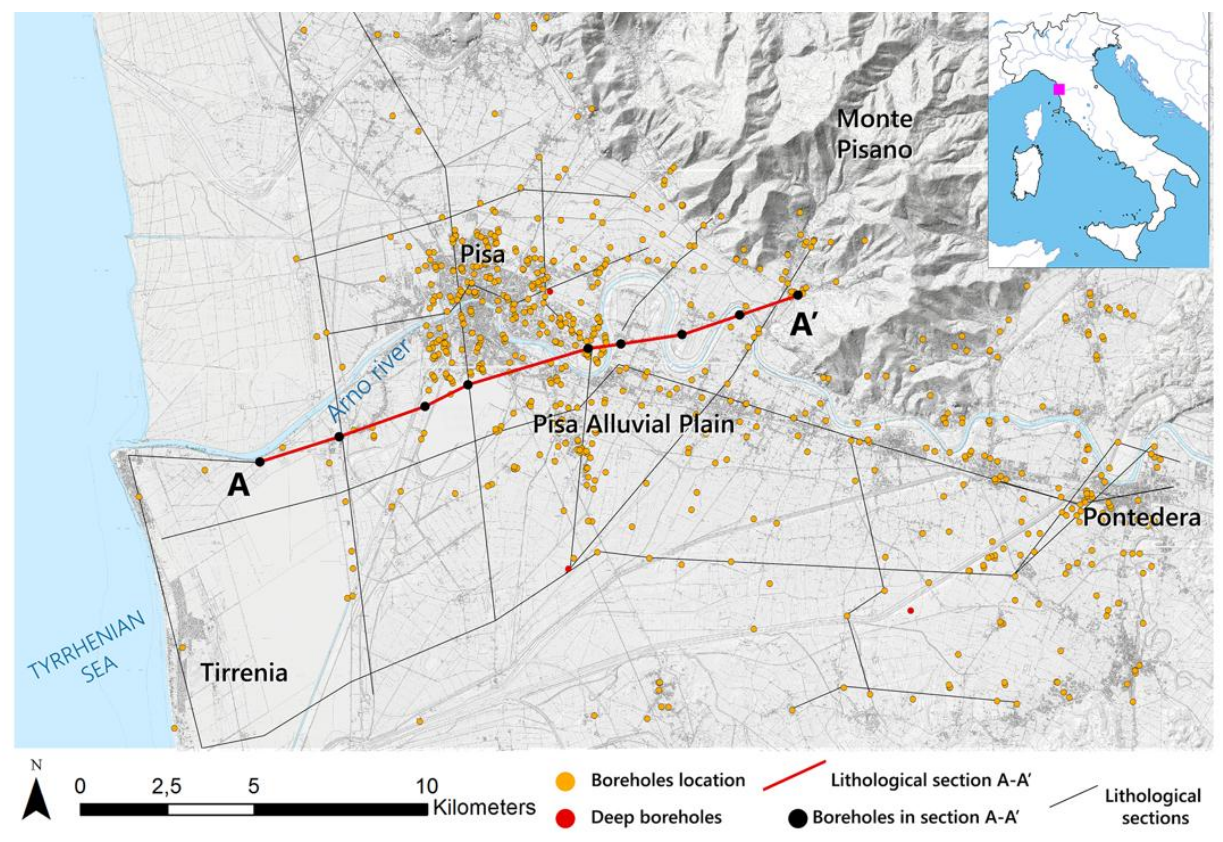

(a)

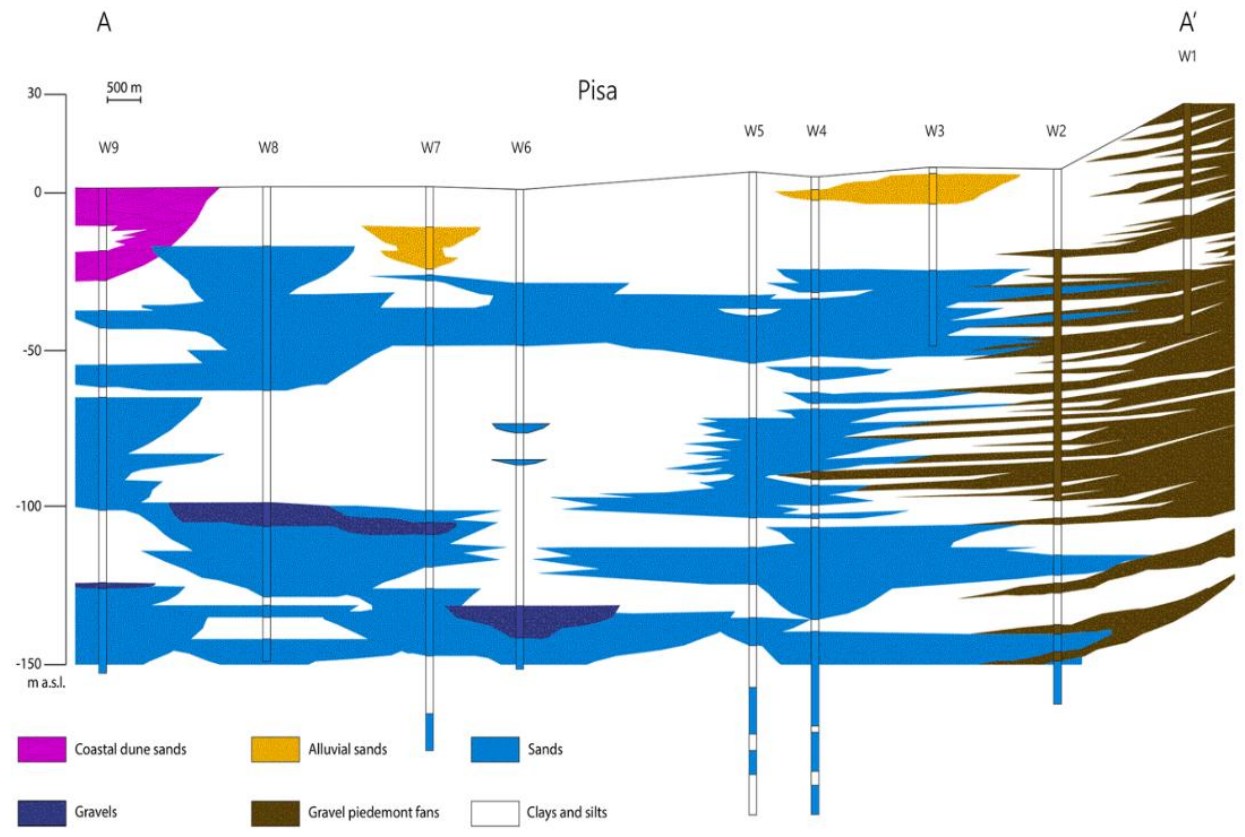

(b)

Figure 2. (a) 2D map with boreholes imported into the geodatabase. Coordinate system: WGS_1984_UTM_Zone_32N (EPSG 32632); (b) Example of a lithological section.

Sands and Gravels Unit (SGU): this unit consists of a succession of sands and gravels. These are separated by a discontinuous Clay Unit (CU) that separates the SGU into the SGU-1 (upper) and SGU-2 (lower) aquifers. Strong lateral heterogeneities are observed in the SGU. This unit, with high permeability (hydraulic conductivity (K) equal to $10^{-3} \mathrm{~m} / \mathrm{s}$ in gravels and $10^{-5} \mathrm{~m} / \mathrm{s}$ in sands), hosts the multilayer aquifer system [33]. 


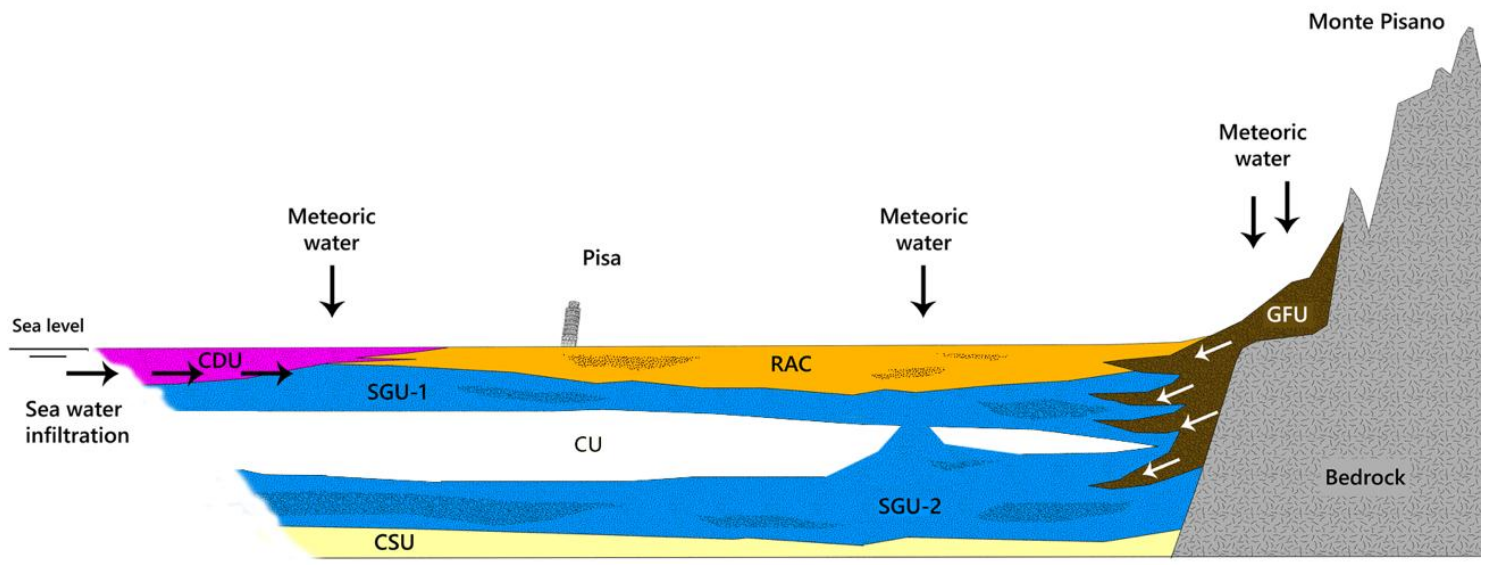

Figure 3. Subsoil conceptual model of the Pisa plain. CDU: coastal dune unit; RAC: recent alluvial cover; GFU: gravel fans unit; SGU-1: sands and gravels upper unit; SGU-2: sands and gravels lower unit; CU: clay unit; CSU: clay and sands unit. SGU-1 and SGU-2 form a multilayered aquifer (SGU).

Clay and Sands Unit (CSU): clayey and sandy sediments below the SGU. Just a few deep boreholes intercept this unit [44].

These units have the following spatial arrangement: the SGU is covered by RAC, which transitions into CDU sediments westward. Fine-grained sediments of the CSU underlie the SGU. The CSU covers the bedrock, which is heterogeneous in lithology and hosts thermal waters. To the east, the GFU (comprising coarse-grained deposits of Monte Pisano alluvial fans) is interdigitated with SGU sediments. Monte Pisano is a major meteoric recharge area for the confined multilayered aquifer hosted by the SGU (Figure 3).

Within the area of interest, the pre-Neogene bedrock has been intersected by two drill holes: the Poggio 1 well, drilled for gas exploration, and the geothermal well San Cataldo 1 [17]. The former, located about $7 \mathrm{~km}$ SSE of Pisa, encountered carbonate Mesozoic formations at $693 \mathrm{~m}$ below ground level (bgl), whereas the latter, drilled at the eastern periphery of Pisa township, intersected the same units at $570 \mathrm{~m}$ bgl. From geophysical data, the thickness of the carbonate formations has been estimated [17] to be around $1500 \mathrm{~m}$. Other drill holes, Zannone and Tombolo 1, located just outside the area of interest, have also intersected the pre-Neogene basement (at $360 \mathrm{~m}$ and $2493 \mathrm{~m}$ bgl, respectively) encountering different formations, Scaglia and Macigno, respectively. The locations of the above drill holes are shown in Figure 4.

A detailed gravity survey, using roughly 1000 stations evenly distributed over an area of $220 \mathrm{~km}^{2}$, was used to reconstruct the geometry of the bedrock and to define the main buried structures affecting the Pisa sedimentary plain, as required for the subsequent geothermal modeling. All the gravity measurements were processed according to the standard procedures [45]. The theoretical g values were computed using the GRS80 formula [46]. The free-air correction used the formula that considers the station latitude and the second-order term of the height. The Bouguer correction, with the Bullard $\mathrm{B}$ term, reduces the infinite Bouguer slab to a spherical cap. Finally, the terrain was corrected, up to $30 \mathrm{~km}$, with curvature correction beyond $10 \mathrm{~km}$, using a right rectangular prism algorithm [47]. The corrections were computed using a mass density of $2300 \mathrm{~kg} \cdot \mathrm{m}^{-3}$.

The resulting Bouguer anomaly map (Figure 4) is the summation of the gravity effects related to both deep and shallower anomalous bodies. Several strategies were introduced to separate the contributions of the deeper sources from the shallower ones. In particular, an upward continuation procedure, horizontal and vertical gradient analysis and least-squares residual anomaly separation, were applied to the Bouguer anomaly data.

Inversion was effected using a modified Bott's algorithm [48], which, besides other refinements, considers spatially variable hyperbolic depth-density functions, thus including the different 
compaction rates within the basin fill in the modeling process. Accounting for the lateral and depth variation of density resulted in very robust outcomes: e.g., without applying any constraints, the solution quickly converged to an upper surface for the bedrock that was within $2 \%$ of the San Cataldo 1 and Poggio 1 control points.

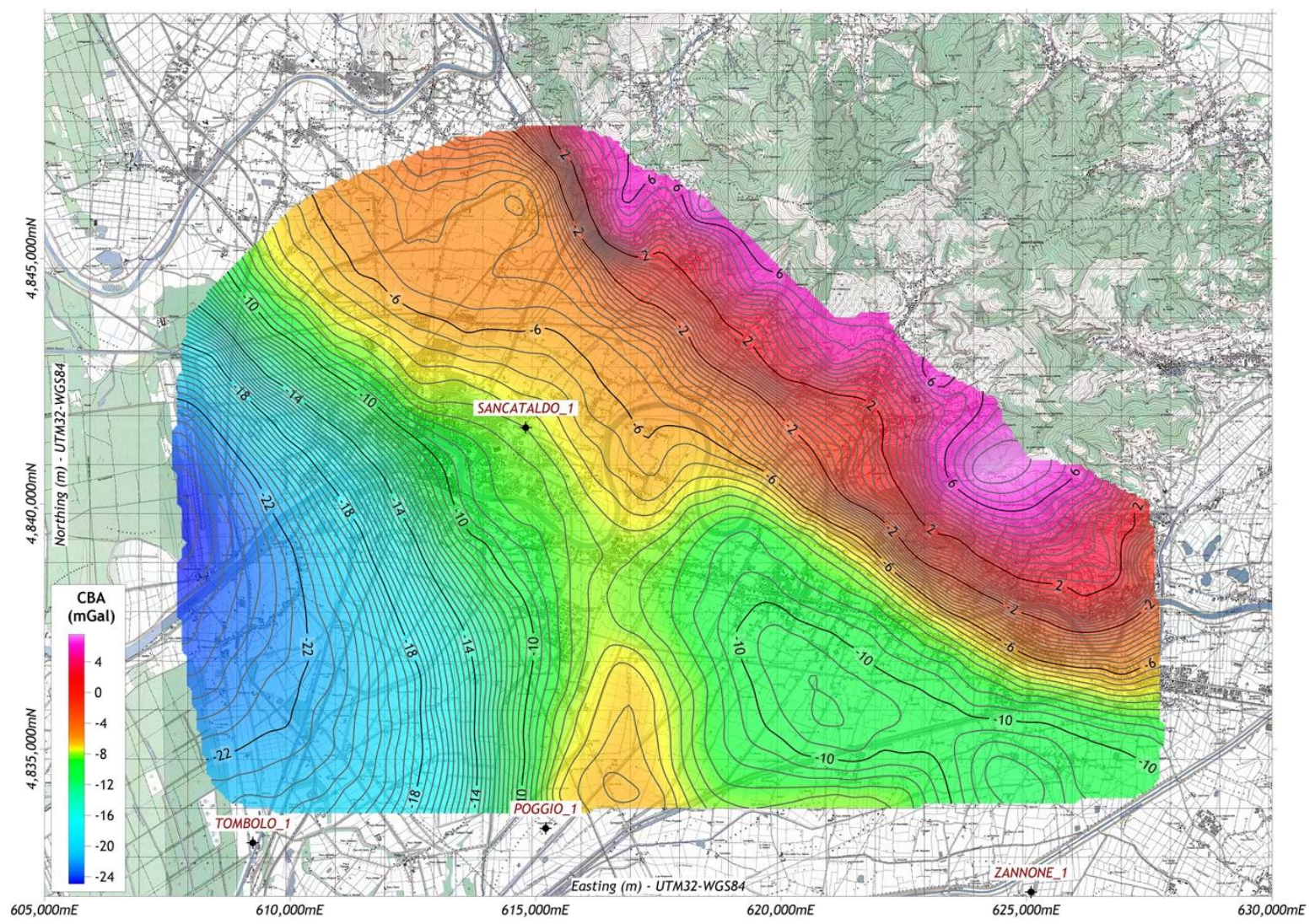

Figure 4. Gravimetric survey of the Pisa plain: Bouguer anomaly map, after residualization.

Two master faults dominate the deeper structure of the basin (Figure 5), both with downthrow on the western side. One is at the base of the Monte Pisano, almost rectilinear and parallel to the mountain range; the other is curved and more northerly oriented, and just west of the Pisa township. The sector within the two faults is a structural high, bordered on either side toward the south by significant lows. This setting could be interpreted as the result of block tilting, arising from the development of listric geometries along the easternmost fault.

\subsection{D Modeling}

The geothermal GIS data were transferred to a 3D Petrel database in accordance with the framework defined in the subsoil conceptual model. A DTM (cell size $10 \times 10 \mathrm{~m}$ ), public data from the Tuscany Region website [49], was imported to elaborate the topographic surface.

As with the GIS, the Petrel project was set to the WGS_1984_UTM_Zone_32N (EPSG 32632) coordinate system, and 712 wells (Figure 2a) were selected and imported with their names, latitudes, longitudes, elevations, and depths. Down each borehole, profile well tops were located at the tops of lithological units, in accordance with the proposed conceptual model (Figure 3). Lithological sections were used as additional inputs. Well tops and additional inputs were processed through make/edit surface tools to create the surfaces and the isobaths of the different units. Surfaces were modeled using the "convergent interpolation algorithm" (Petrel ${ }^{\circledR}, 2010$, Schlumberger-Software Integrated Solutions, 
Parma, Italy), producing regular mesh grids of $50 \times 50 \mathrm{~m}$. Finally, each solid unit was developed from these surfaces. Together, these solid units form the 3D geological model of the Pisa basin (Figure 6).

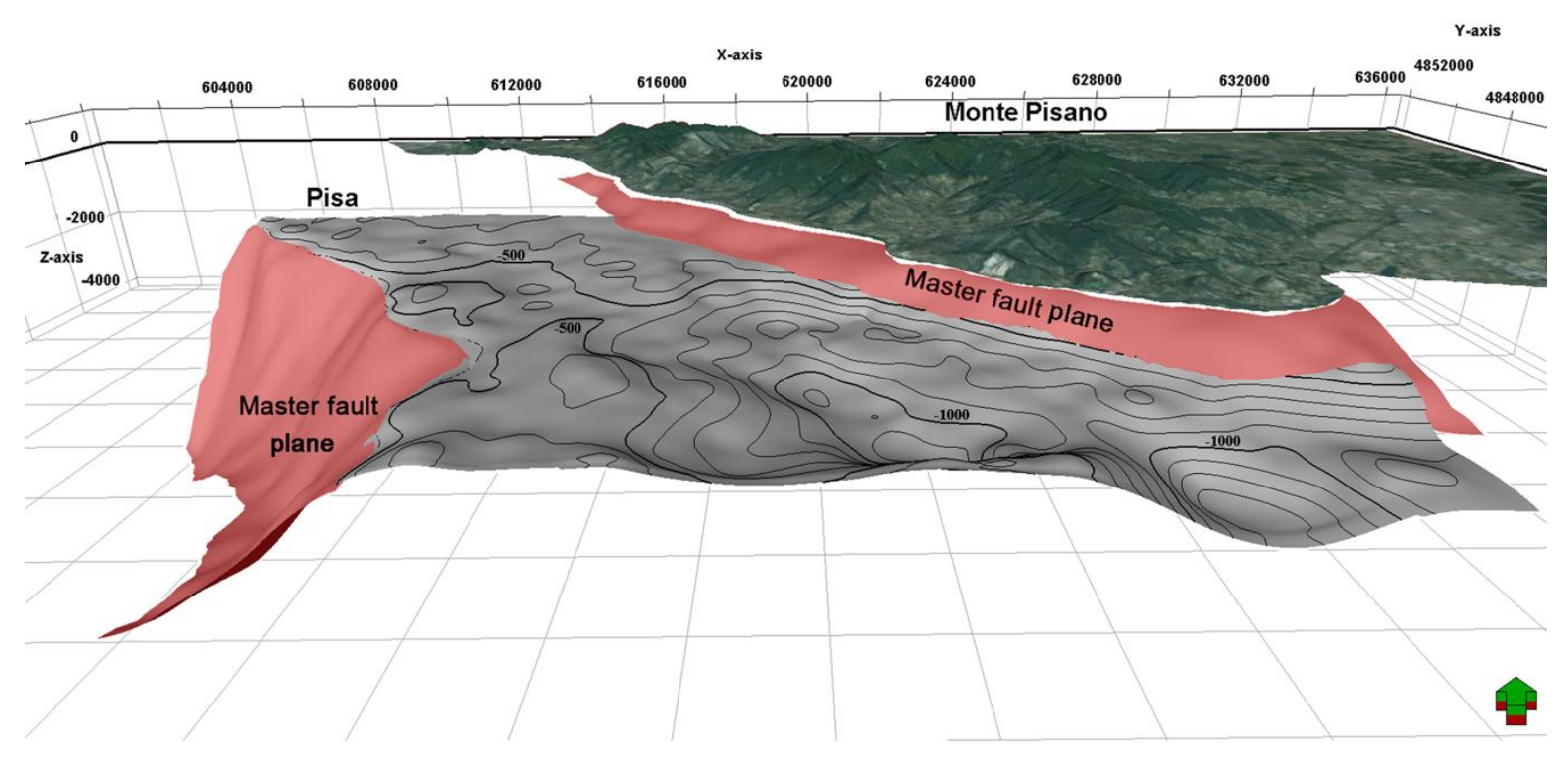

Figure 5. 3D view of the bedrock upper surface (isobaths in $\mathrm{m}$ a.s.l) and master faults of the basin. Elaborated by the inversion of gravity data. Coordinate system in meters.

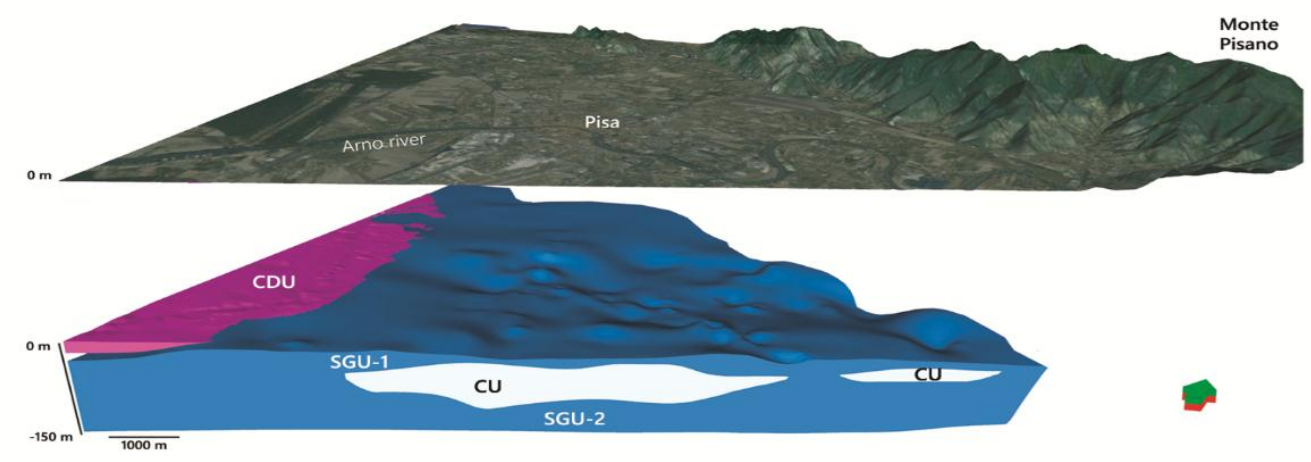

Figure 6. Section of the 3D model of the selected area. Underground vertical exaggeration: $10 \times$. Topographic surface vertical exaggeration: $2 \times$.

\subsection{D Geothermal Modeling}

The surfaces of the lithological units were imported as .txt files into PetraSim 5, the graphic interface for the TOUGH2 geothermal calculation code, to produce the geothermal model. Knowledge of bedrock geometry, obtained by gravity data inversion, also has a fundamental role in thermofluidodynamic simulation because bedrock acts as the heat source for the shallower portion of the investigated system. The simulation (Figure 7) therefore included the portion of the Pisa plain delimited by the two master faults and the areal limits of the gravimetric survey (Figure 5).

A grid with a horizontal cell size of $200 \times 200 \mathrm{~m}$ was applied to the data. The vertical cell size varied by layer. Each unit, irrespective of its thickness, was subdivided into 10 cells using the top surfaces imported from Petrel (Figure 7).

Therefore, the grid was denser in the upper part of the model, where the reconstructed subsurface units had higher definition (Figure 7). This allowed detailed thermal characterization of the units and 
aquifers (up to $200 \mathrm{~m}$ depth) most suitable for energy exploitation. Measured or literature-derived values for the density, permeability, porosity, thermal conductivity, and specific heat were associated with the cells in each lithostratigraphic unit (Table S1, see Supplementary Materials).

Grid size selection was influenced by the maximum number of cells possible without imposing an excessive computational load (about 40,000 cells), considering also the iterations necessary to reach the best fit between the measured and calculated data. The grid could be modified locally to better resolve output temperatures in smaller selected areas.

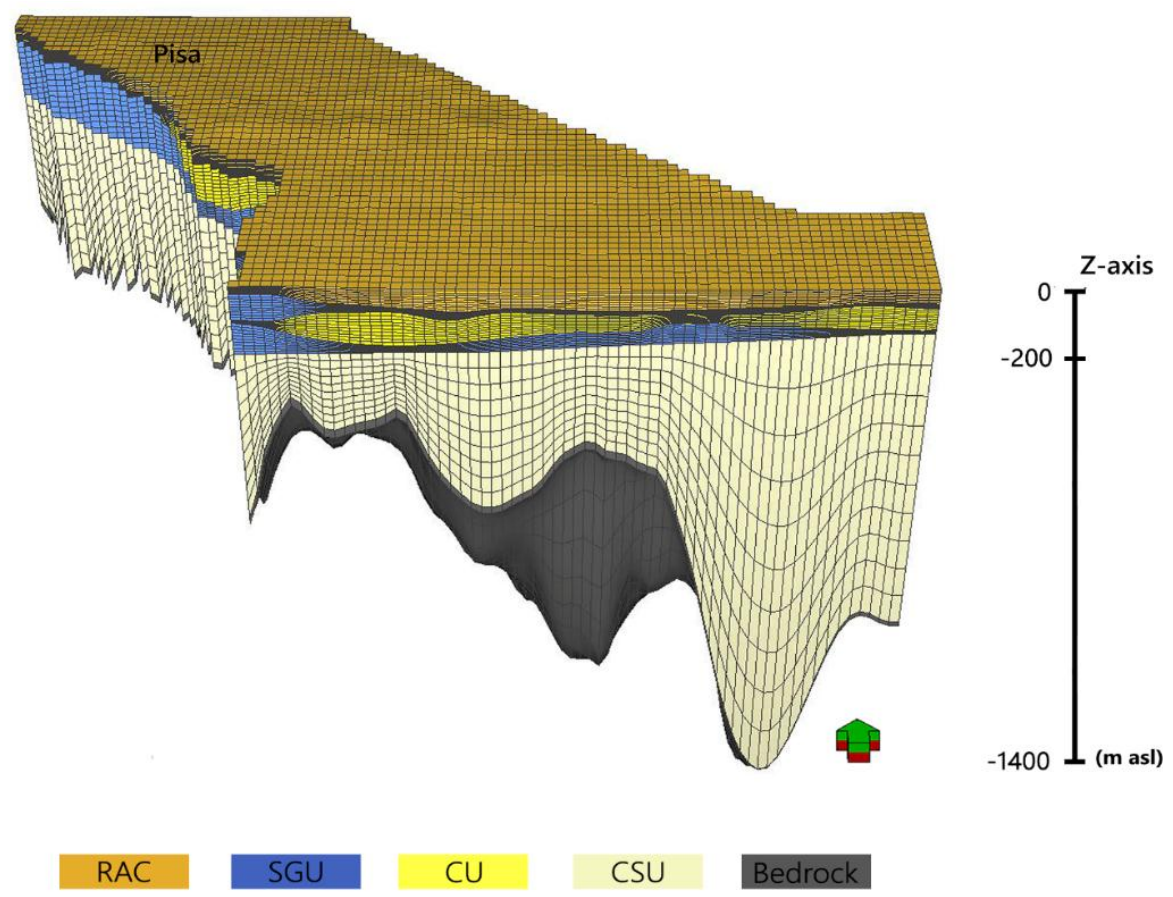

Figure 7. Section of the 3D model of the selected area. Underground vertical exaggeration: $10 \times$. Topographic surface vertical $2 \times$. RAC: recent alluvial cover; SGU: sand and gravel unit; CU: clay unit; CSU: clay and sands unit.

To run the simulation, input values of the temperature and pressure were assigned to each cell in the top and bottom layers of the model. Input pressure values followed a hydraulic pressure gradient. The average atmospheric temperature for the area is $16^{\circ} \mathrm{C}$ (for the years 1942-2016, Pisa meteorological station) [50] and this was assigned as the constant input temperature at the top of the model (coinciding with the DTM surface) for the whole area (Figure 8).

Several tests were performed before assigning temperatures at the bottom of the simulation volume, i.e., the top of the sedimentary basin bedrock. This is critical because the bedrock temperatures control the heat transfer from the bedrock surface to the overlying sediments. Firstly, a constant temperature of $50{ }^{\circ} \mathrm{C}$ was assumed at the heating plate (the top surface of the bedrock) in accordance with temperatures measured inside the geothermal reservoir in the San Cataldo 1 well [17]. Secondly, as the bedrock top surface has an irregular shape, and hence variable depth, temperatures were calculated based on the local geothermal gradient $\left(50-60^{\circ} \mathrm{C} \cdot \mathrm{km}^{-1}\right)[16,17]$. According to calculation based on local geothermal gradient, temperatures at the bedrock top varies from about $32{ }^{\circ} \mathrm{C}$ in the North West portion of the simulation volume, to about $90^{\circ} \mathrm{C}$ in the its South East portion (Figure 8).

After each test, the calculated temperatures were compared with direct temperature surveys in boreholes and with measured data from previous works [38]. The results show agreement (deviation $<6 \%$ ) between the measured temperatures for aquifers and the simulated temperatures in the model cells at the corresponding depth in the aquifer. The best result was obtained using a local geothermal gradient value of $56^{\circ} \mathrm{C} \cdot \mathrm{km}^{-1}$, and this represents the steady-state condition of the model (Figure 9). 


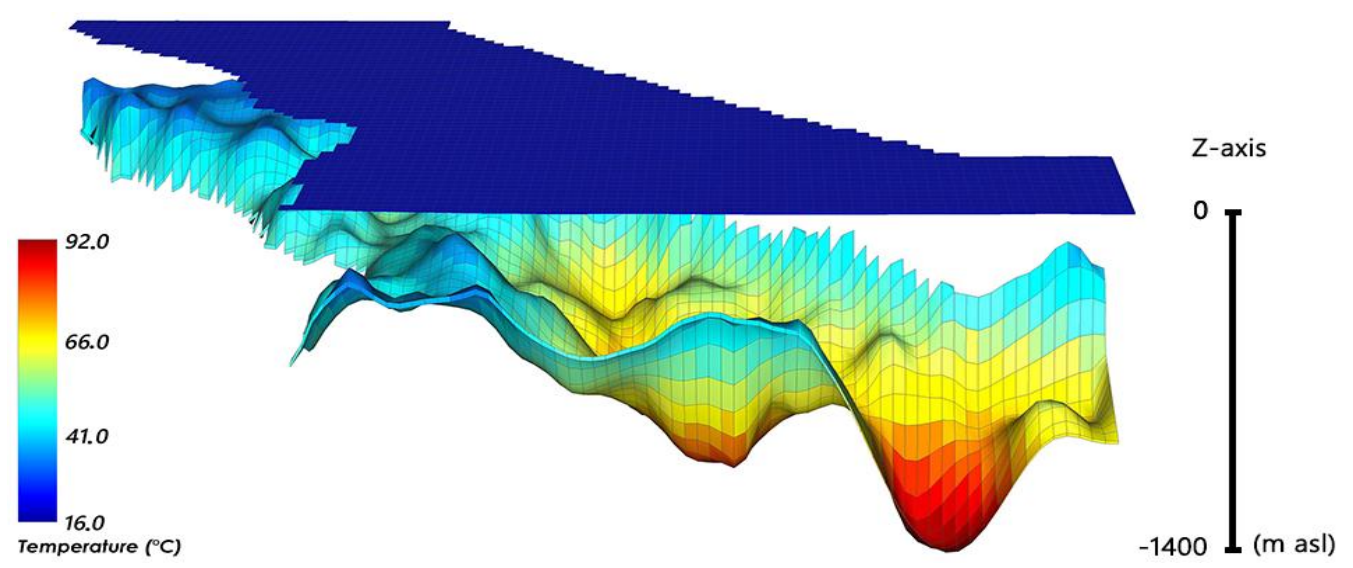

Figure 8. 3D visualization of input temperatures for top and bottom layers of the model: the upper layer coincides with the topographic surface (DTM), while the bottom layer is the top of bedrock. The simulation volume is the same as in Figure 7; see also Figure 5 for isobaths of bedrock top.

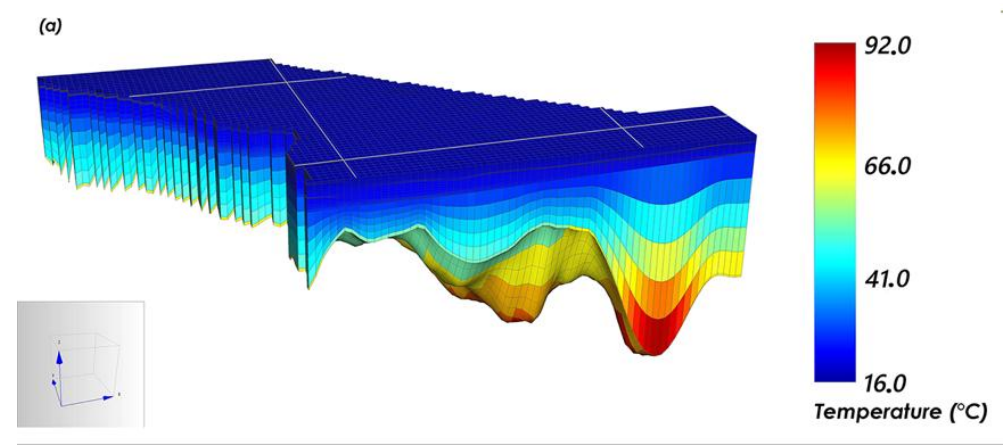

(b)

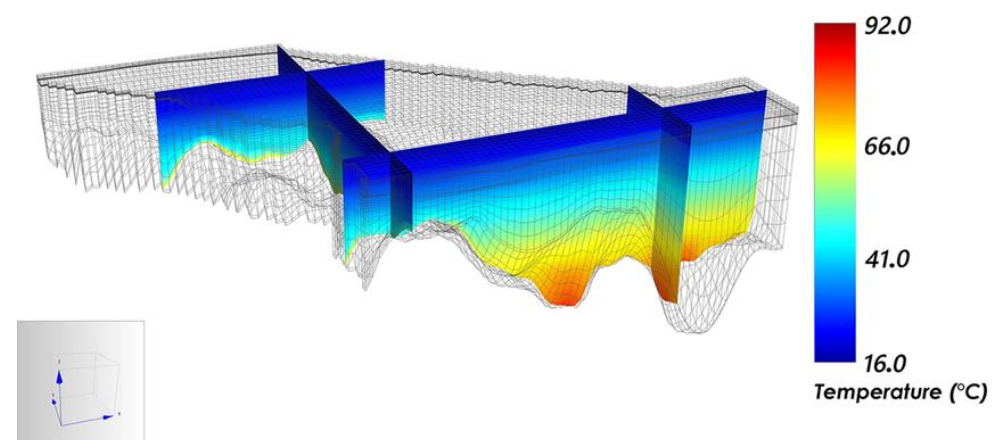

Figure 9. Temperature simulation results in the steady state: (a) Color block plot; (b) N-S and E-W cross-sections. Model volume is the same as in Figures 7 and 8.

The temperature outputs were then exported, in tabular format, with the coordinates of the cell centers. To facilitate data interpretation and visualization, these simulation results (more than 13,000 points with $X, Y$ and $Z$ spatial coordinates and temperature values) were imported into the Petrel software to generate a 3D subsoil temperature distribution model (Figure 10). IDW interpolation produced temperature maps at different depths. 


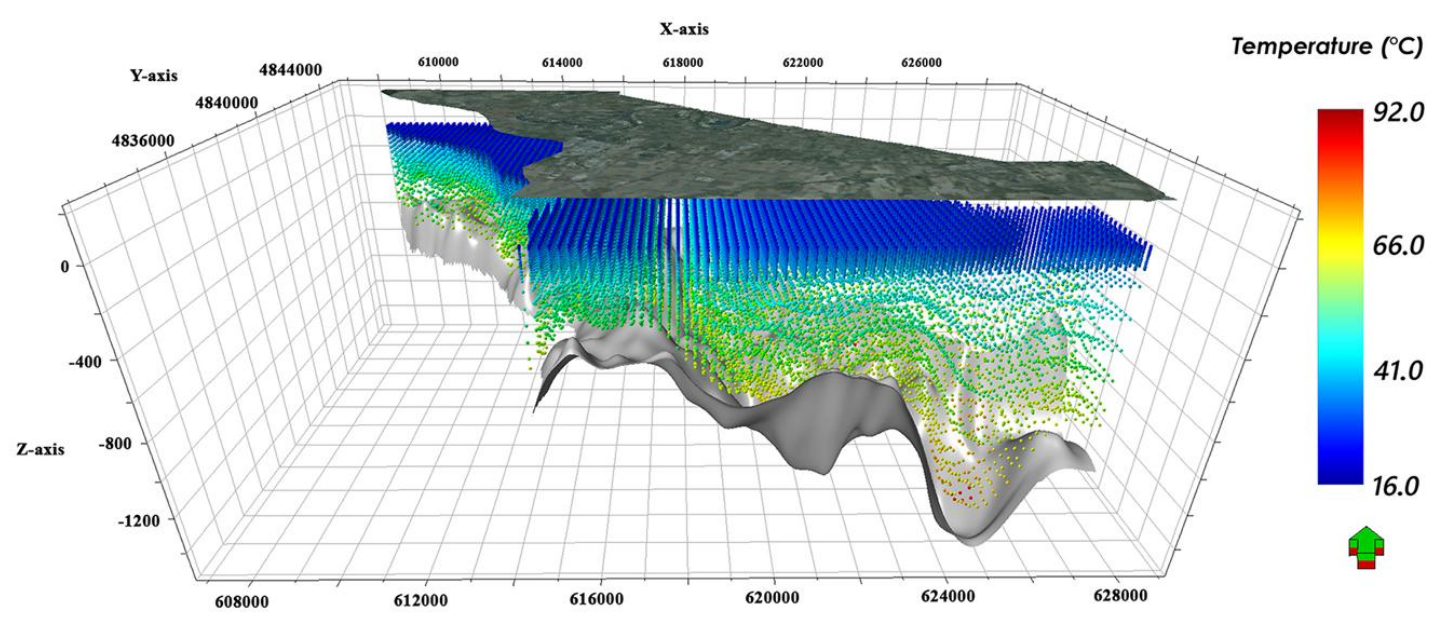

Figure 10. 3D point cloud of temperatures (from TOUGH2 simulation results) imported into the Petrel environment. Colored points indicate temperature values between the topographic (upper) and bedrock (lower) surfaces. Model volume is the same as in Figures 7 and 8. Coordinate system in meters.

\section{Geothermal Applications}

The underground thermal model allows the realization and visualization, using a 3D platform (Petrel) and GIS tools, of different temperature outputs integrating both measured and simulated data. As an example, Figure 11 is a 3D map of temperatures within the first confined aquifer of the SGU (at half thickness). Alternatively, slices at different fixed depths can be produced; Figure 12 shows temperature maps at depths of $-50 \mathrm{~m},-100 \mathrm{~m}$, and $-130 \mathrm{~m}$ a.s.l (i.e., 50,100 , and $130 \mathrm{~m}$ below sea level). The maps show that temperature inhomogeneity affects the subsoil of the Pisa sedimentary plain. Higher temperatures (Figure 12) are observed, beneath Pisa city and north and south of the town, at depths of $50 \mathrm{~m}\left(23^{\circ} \mathrm{C}\right), 100 \mathrm{~m}$, and $130 \mathrm{~m}\left(27^{\circ} \mathrm{C}\right)$, and correspond to the structural highs of the bedrock (Figures 4, 5 and 11). High temperatures $\left(26-27^{\circ} \mathrm{C}\right.$ at $130 \mathrm{~m}$ of depth) are also observed at the eastern limit of the simulation area near the footwall of Monte Pisano. Lower temperatures occur in the central southeastern sector of the simulation area $\left(18{ }^{\circ} \mathrm{C}\right.$ at $50 \mathrm{~m}$ depth and $22{ }^{\circ} \mathrm{C}$ at $\left.130 \mathrm{~m}\right)$, corresponding with a structural low (Figure 5). The differences in subsoil temperatures may have several causes. Cold fresh water coming from the Pisa mountains meteoric recharge area (Figure 3) through the Monte Pisano alluvial fan aquifer reduces local temperatures in the confined multilayered aquifer through recharge of cold meteoric waters. Rising thermal waters in the northeast, near San Giuliano Terme, along master faults of the graben structure (Figure 5), could contribute to the higher temperatures at the eastern limit. The bedrock depth, which is shallower to the north $(-500 \mathrm{~m}$ a.s.l) of the area and deeper in the southeast (from $-1100--1400 \mathrm{~m}$ a.s.l), and the consequent different thickness and type of overlying sediments also affects subsoil temperatures.

An "urban heat island" effect, already well described for shallow aquifers in densely inhabited towns [51], because of thermal pollution, may be responsible for the shallow (50 $\mathrm{m}$ a.s.l), positive temperature anomaly (Figure 12b) observed below Pisa downtown.

Simulation modeling provides a detailed thermal characterization of subsoil units and aquifers and so can support the choice of geothermal heat mining technology, allowing the shallow and low temperature geothermal resource of Pisa area to be utilized for heating and cooling through either open- or closed- loop GHPs. The resource present at higher depths, in permeable fractured carbonate formations in the areas of shallow bedrock, could be exploited for geothermal district heating $(\mathrm{GeoDH})$ with direct use of thermal fluids and heat pumps. The thermal characterization of the subsoil (Figures 10-12), derived by the integration of measured and simulated temperatures, allows us to calculate the energy potential of the subsoil and hence the suitability of the different geothermal technologies. 


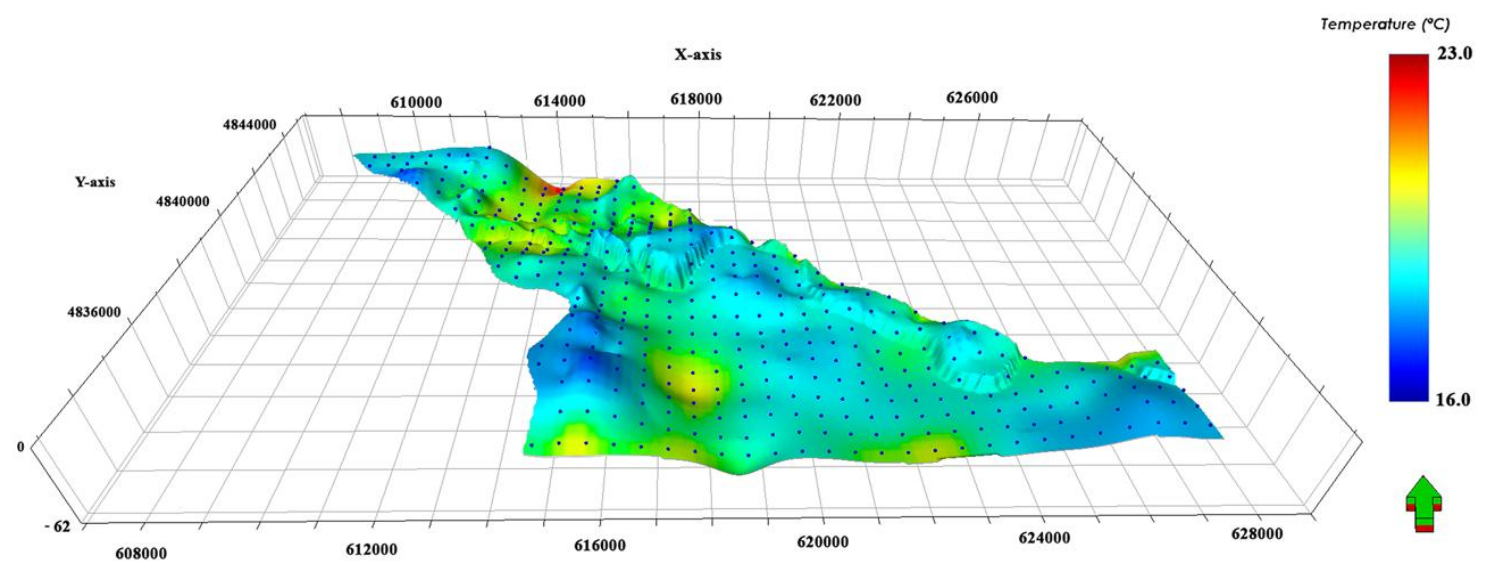

Figure 11. 3D visualization of temperature of SGU-1 at aquifer mid-depth, in the Petrel workspace. Vertical exaggeration: $30 \times$. Coordinate system in meters.

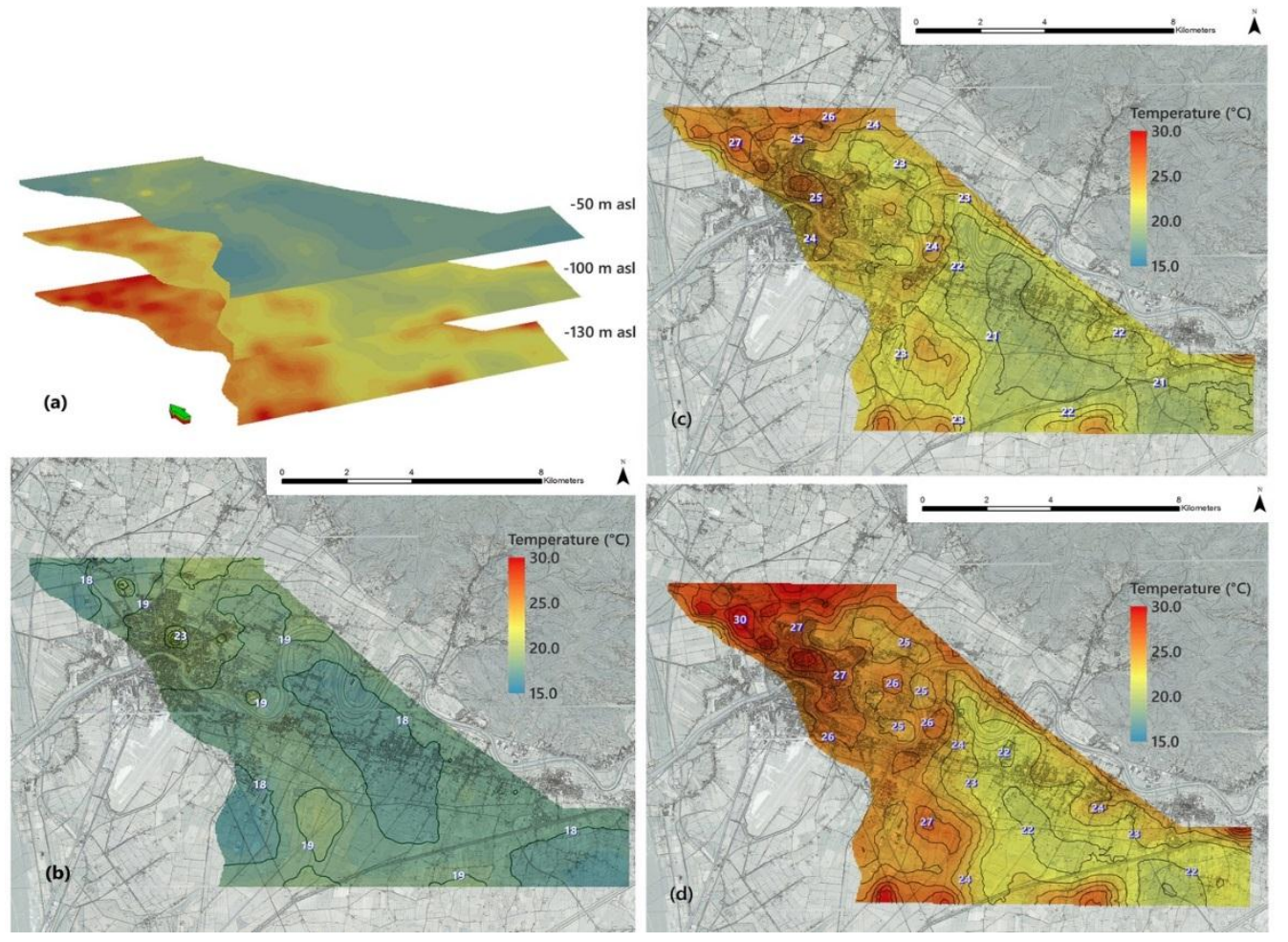

Figure 12. Maps of isotemperatures obtained using IDW interpolation of 3D point cloud of temperature, see Figure 10. (a) 3D visualization. (b) $2 \mathrm{D}$ visualization at $-50 \mathrm{~m}$ a.s.l. (c) $2 \mathrm{D}$ visualization at $-100 \mathrm{~m}$ a.s.l. (d) 2D visualization at $-130 \mathrm{~m}$ a.s.l. In (b-d), isotemperature contours are also shown.

\subsection{Evaluation of the Geothermal Potential for Open-Loop GHP Systems}

The heat stored in the phreatic or confined aquifers may be mined through doublets of wells (both production and reinjection wells) and a heat exchanger that represents the interface with the heat pump. This type of assemblage allows heat to be sustainably mined, without any loss or contamination of water, because all the water from the production well is reinjected restoring the hydraulic capacities of the aquifer.

The geothermal potential of the aquifers of the Pisa plain subsoil can then be estimated using the volumetric method equation [23,24]: 


$$
\mathrm{Q}=\mathrm{Qw}+\mathrm{Qs}=\mathrm{V} n \mathrm{Cw} \Delta \mathrm{T}+\mathrm{V}(1-\mathrm{n}) \mathrm{Cs} \Delta \mathrm{T}
$$

in which $\mathrm{Q}(\mathrm{kJ})$ represents the potential heat content of the aquifer, while $\mathrm{Qw}$ and $\mathrm{Qs}(\mathrm{kJ})$ are the heat content stored in groundwater and sediments, respectively. $\mathrm{V}\left(\mathrm{m}^{3}\right)$ is the aquifer volume, $\mathrm{n}$ is the porosity, $\mathrm{Cw}$ and $\mathrm{Cs}\left(\mathrm{kJ} \cdot \mathrm{m}^{-3} \cdot \mathrm{K}^{-1}\right)$ are the volumetric heat capacity of water and solids, respectively, and $\Delta \mathrm{T}(\mathrm{K})$ is the difference between the undisturbed temperature of the aquifers/sediments and the temperature after heat mining. The volume of the SGU was obtained from the elaboration of the 3D model, using Petrel tools. The true volume of the lower part of the SGU, and hence its thermal potential, would be less than the modeled volume because it includes minor interlayered clay deposits. These were not modeled because of poor information in the deeper wells. Using this formula, the SGU (SGU-1 + SGU-2) aquifer system contains $3.81 \times 10^{13} \mathrm{~kJ}$ stored in groundwater and $5.76 \times 10^{13} \mathrm{~kJ}$ stored in solid rock, sands, and gravels (Table S2, see Supplementary Materials ). However, not all this energy can be effectively exploited, as open-loop GHP technology can use only the energy stored in groundwater. Assuming a recovery factor of 10\% [52], the exploitable energy in the SGU aquifer is $3.81 \times 10^{12} \mathrm{~kJ}$ or $1.06 \times 10^{6} \mathrm{MWh}$. The ArcGIS tool "raster calculator" was used to apply the formula within each raster cell $(50 \times 50 \mathrm{~m})$ and thus map the geothermal potential for open-loop systems down to a depth of $150 \mathrm{~m}$ (the depth of SGU-2) (Figure 13). To assess the value of the resource relative to potential demand, a heating period of 200 days, derived from the national subdivision of climatic zones, was used [53]. Higher potentials (Figure 13) correspond to areas richer in sands, and consequently water, in the subsoil volume. Lower potentials occur in areas with more clay-rich lithologies. This helps in selecting the best areas for adoption of open-loop systems.

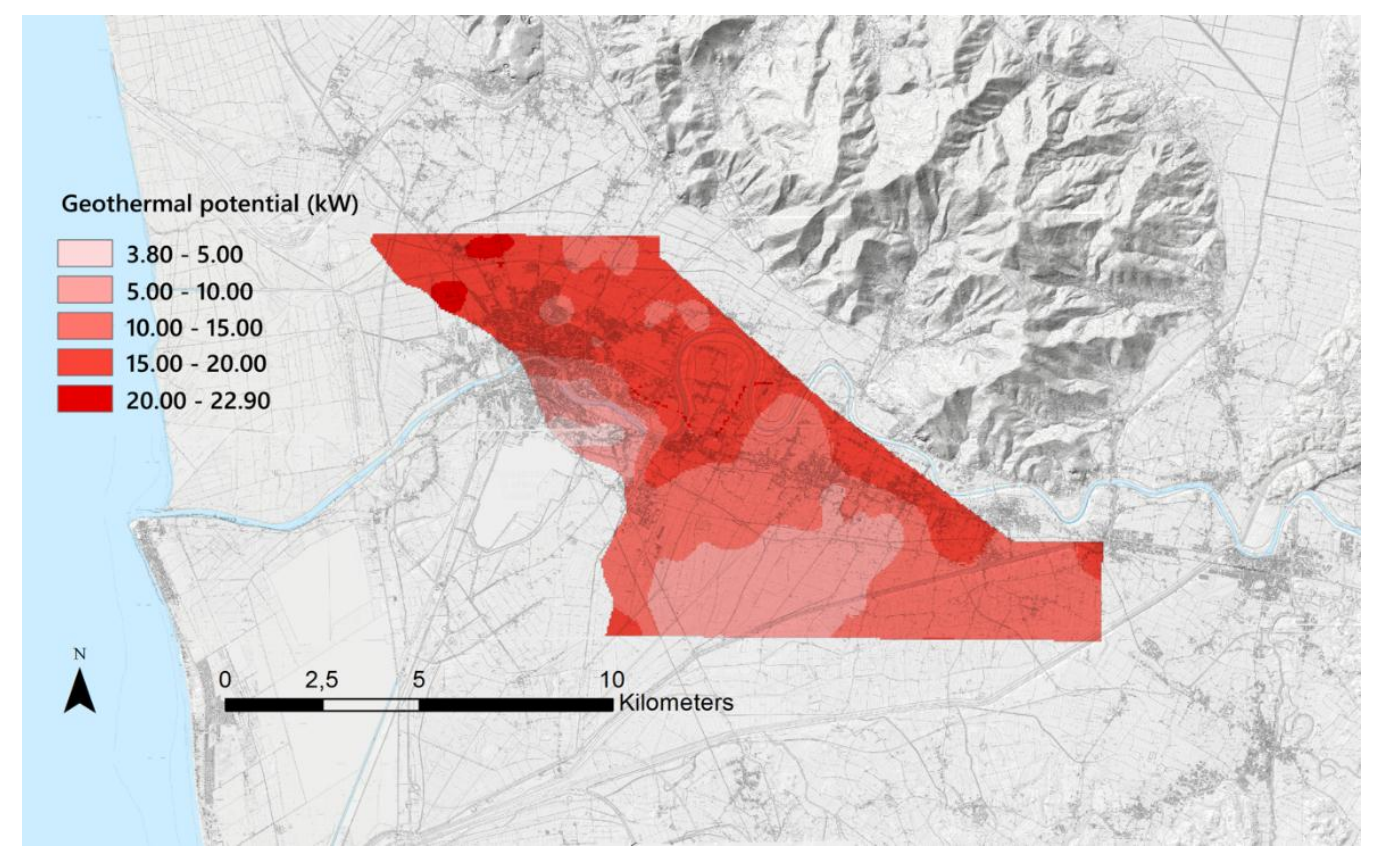

Figure 13. Geothermal potential $(\mathrm{kW})$ for heating using a geothermal open-loop system. Depth: $150 \mathrm{~m}$.

\subsection{Evaluation of the Geothermal Potential for Closed-Loop GHP Systems}

The heat stored in the subsoil can also be exploited by the means of vertical borehole heat exchangers (BHEs) connected to a heat pump; heat is extracted from the ground using closed-loop pipes in which a fluid (usually water) circulates. The vertical pipes are cemented with special high-conductivity grout to sediments or rocks at the wall of the borehole. The thermal conductivity, heat capacity and undisturbed temperature of the subsoil affect the thermal exchange between the ground and the BHEs. These parameters vary from place to place, and are linked to the geological, 
hydrogeological and geothermal settings of the site where the system is installed. An accurate knowledge of these parameters is fundamental for correct dimensioning of the system. The number and length of BHEs required for the closed-loop system depends on the thermal characteristics of the subsurface and on the required heating (or cooling) capacity.

Evaluation of the geothermal potential of closed-loop systems is commonly based on specific software (i.e., EED, Earth Energy Designer) or tabular data [54]. In this work, the geothermal potential of closed-loop systems was evaluated applying the "G.POT" (Geothermal POTential) method [55]. As above, we considered a heating period of 200 days [53].

Ground thermal properties were derived from the numerical simulation and the literature. The ground thermal conductivity $\left(\mathrm{W} \cdot \mathrm{m}^{-1} \cdot \mathrm{K}^{-1}\right)$ was depth-averaged over the first 100 meters, which represents the average length of BHEs (Figure 14).



Figure 14. Thermal conductivity map $\left(\mathrm{W} \cdot \mathrm{m}^{-1} \cdot \mathrm{K}^{-1}\right)$, weighed average over $100 \mathrm{~m}$ depth.

The mapping used the thermal conductivity values and thicknesses of alluvial deposits adopted for the numerical simulation. For the mostly clayey sediments a value of $1.8 \mathrm{~W} \cdot \mathrm{m}^{-1} \cdot \mathrm{K}^{-1}$ was used, while for the mostly sandy aquifer a value of $2 \mathrm{~W} \cdot \mathrm{m}^{-1} \cdot \mathrm{K}^{-1}$ was assigned. Horizontal variations in thermal conductivity are linked to different thicknesses of clayey and sandy sediments. The highest values of thermal conductivity occur in areas where clay sediments are subordinate to the sandy aquifer. The temperature distribution $\left({ }^{\circ} \mathrm{C}\right.$ ) at $50 \mathrm{~m}$ depth (Figure $12 \mathrm{~b}$ ) derived from the numerical simulation was used as the undisturbed temperature of the ground. Assuming a BHE length of $100 \mathrm{~m}$, the temperature at $50 \mathrm{~m}$ depth can be adopted as the mean temperature along the pipe. Volume-related specific heat capacity values were derived from guidelines [54]: a value of $2.5 \mathrm{MJ} \cdot \mathrm{m}^{-3} \cdot \mathrm{K}^{-1}$ was used.

A standard vertical BHE was used, according to prior methodology [55], for evaluation of the geothermal potential throughout the area. The parameters for this BHE, needed for the calculation of borehole thermal resistance and heat transfer with the ground, are listed in Table S3 (see Supplementary Materials).

Figure 15 shows the distribution of geothermal potential, for single standard vertical BHE, based on the use of closed-loop technology. Comparing the calculated $\mathrm{kW}$ values with the thermal conductivity (Figure 14) and undisturbed temperature of the ground (Figure 12b), it is immediately clear that the highest thermal potential $(4.75 \mathrm{~kW})$ occurs in the areas of highest thermal conductivity and temperature. The highest temperature values are indicated as being north of the Arno river. 
The whole investigated area is very promising for the installation of closed-loop systems, since from a single vertical BHE, between 3.5 and $4.75 \mathrm{~kW}$ can be extracted for heating purposes. Generally, a GHP plant would include more than 1 vertical BHE, depending on the power of the GHP and heating requirements of the buildings.

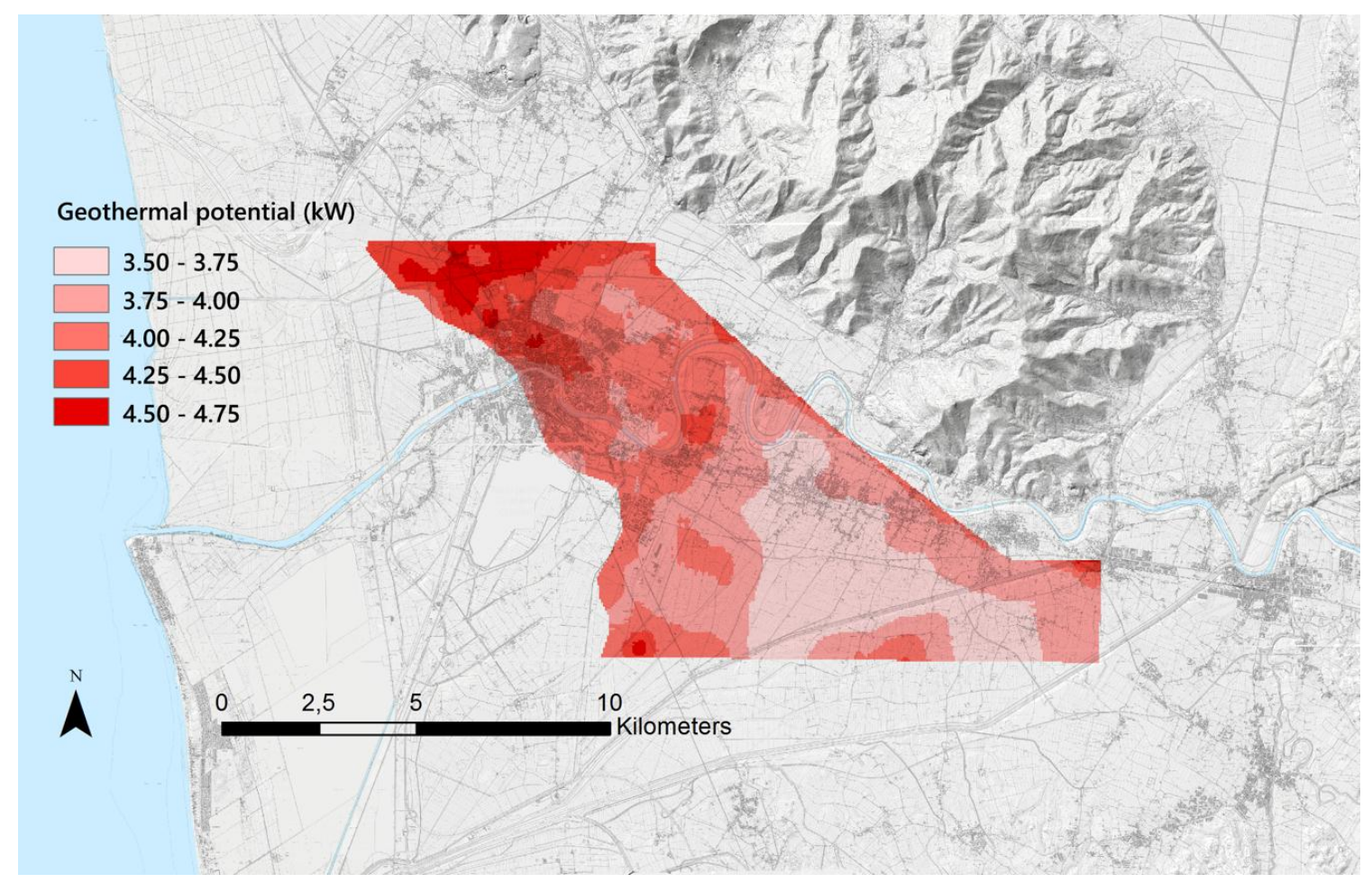

Figure 15. Geothermal potential $(\mathrm{kW})$ for heating-only by geothermal closed-loop systems (for 1 standard vertical BHE). Depth: $100 \mathrm{~m}$. The calculation follows [46] QBHE $=[\mathrm{a}(\mathrm{T} 0-\mathrm{Tlim}) \lambda \mathrm{L}$ $\left.t^{\prime} \mathrm{c}\right] /\left[-0.619 \mathrm{t}^{\prime} \mathrm{c} \log \left(\mathrm{u}^{\prime} \mathrm{s}\right)+\left(0.532 \mathrm{t}^{\prime} \mathrm{c}-0.962\right) \log \left(\mathrm{u}^{\prime} \mathrm{c}\right)-0.455 \mathrm{t}^{\prime} \mathrm{c}-1.619+\pi \lambda \mathrm{Rb}\right]$; where QBHE $(\mathrm{MWh} / \mathrm{y})$ is the geothermal potential for a standard vertical BHE for heating only, $\mathrm{a}=0.0701$, T0 is the ground undisturbed temperature, Tlim is the minimum temperature of the heat carrier fluid, $\lambda$ is the ground thermal conductivity, $\mathrm{L}$ is the length of the pipes, $\mathrm{t}^{\prime} \mathrm{c}=\mathrm{tc} / 365$ where $\mathrm{tc}$ is the heating period, $\mathrm{Rb}$ is the borehole thermal resistance, $\mathrm{u}^{\prime} \mathrm{s}=\mathrm{rb} 2 /(4 \alpha \mathrm{ts})$ and $\mathrm{u}^{\prime} \mathrm{c}=\mathrm{rb} 2 /(4 \alpha \mathrm{tc})$ where $\mathrm{rb}$ is the borehole radius, $\alpha=\lambda / \rho c$ is the thermal diffusivity of the ground and ts is the operating time of the system. For a more practice use, we derived $\mathrm{kW}$ values from the calculated $\mathrm{MWh} / \mathrm{y}$.

\subsection{Evaluation of the Geothermal Potential for the Bedrock}

As previously stated, the temperatures in bedrock range between $40^{\circ}$ and $90^{\circ} \mathrm{C}$ at depths from $500 \mathrm{~m}$ to $1400 \mathrm{~m}$ bgl. The bedrock is formed by carbonate formations, possibly hosting thermal fluids. These fluids may be utilized directly or increasing their temperature (before using fluids) through GHP or other technologies, in GeoDH plants.

The evaluation of this type of geothermal resource, deeper and hotter than those described above, was performed using the volumetric method $[23,24]$ and the reconstructed bedrock unit. For economic reasons (well drilling cost), the calculation was limited to the area where carbonate formations hosting thermal waters are relatively shallow $(<600 \mathrm{~m}$, structural high of the bedrock. The volume, over an area of $53 \mathrm{~km}^{2}$, assuming a constant thickness of $200 \mathrm{~m}$, is $10.6 \mathrm{~km}^{3}$. The parameters used for the bedrock geothermal potential calculation are summarized in Table S4 (see Supplementary Materials). The geothermal energy potential contained within the first $200 \mathrm{~m}$ of the bedrock, limited to the area of gravimetric structural high, is equal to $8.30 \times 10^{14} \mathrm{~kJ}$, or $2.31 \times 10^{8} \mathrm{MWh}$. 
Except for information from the S. Cataldo 1 and Poggio 1 deep wells, no data regarding the nature and permeability of the bedrock lithologies are available. Consequently, the calculated geothermal potential is to be considered only as approximate guidance.

\subsection{Sustainability}

The detailed 3D thermofluidodynamic modeling of subsoil defined by the steady-state conditions of the simulated volume (Figures 8 and 9), represents a snapshot of the Pisa plain system before any geothermal utilization. This is the undisturbed situation but would be affected by heat mining. To determine the level of sustainable use of the resource, it would be appropriate to undertake dynamic modeling, inserting in the 3D model and simulator shallow or deep doublets of wells or vertical BHE, and hence determine the impact on the subsoil resource of GHP and GeoDH exploitation. This would be an important result because it provides a means of regulating application of these technologies to avoid environmental impacts on the subsoil thermal state or on the water resource.

\section{Conclusions}

This paper demonstrates a methodology for assessment of renewable geothermal resources, based on the collection, storage, interpretation, and visualization of a large volume of data in a 3D environment, allowing optimal use of such information.

Application of this methodology to the alluvial-sedimentary geological environment of the Pisa plain, indicates that geological modelling and geothermal numerical simulations, can provide data on the amount of energy that shallow geothermal resources (sediments, rocks, and water) can furnish, including evaluation of the local shallow geothermal (low temperature) potential for GHP (open or closed loop systems) or for wider area heat mining from deeper and hotter geothermal aquifers. The study area was found to have high geothermal potential: the heat stored in water and rocks, up to $150 \mathrm{~m}$ depth, is about $2.5 \times 10^{7} \mathrm{MWh}$. Thematic maps provided spatially explicit estimation of the geothermal potential of different heat exchange technologies, supporting the optimal design of heating and cooling plants.

Low-temperature geothermal resources are ubiquitous in the shallow earth crust, making our approach (as exemplified in the case study) widely replicable. The approach produces information about local geothermal resources, guiding low temperature geothermal plant designers, geologists, and engineers, towards the most efficient solution for a specific site. In particular, knowledge of subsoil geology, derived from 3D reconstruction and a well-geodatabase, can facilitate the diffusion of GHP technology by supporting site selection and drilling of well doublets (for GHP open-loop systems) or vertical heat exchangers (for GHP closed-loop systems).

The methodology not only identifies favorable locations for a specific exchange technology, but also provides a robust conceptual model of the subsoil and supports the thermofluidodynamic modeling necessary for design of sustainable plants that preserve the thermal state of subsoil over the long-term. This approach can ensure environmental sustainability through best practice in the design and regulation of GHP and GeoDH systems, with their attendant environmental benefits.

Supplementary Materials: The following are available online at http:/ /www.mdpi.com/1996-1073/11/6/1591/ s1, Table S1: Initial conditions and parameters for TOUGH2 simulation, Table S2: Geothermal energy calculation (Balke, 1977, Muffler and Cataldi, 1978), Table S3: Parameters for the standard vertical BHE, Table S4: Bedrock geothermal potential calculation (Balke, 1977, Muffler and Cataldi, 1978).

Author Contributions: Conceptualization, A.S. and P.M.; Methodology, A.S., P.M. and G.P.; Validation, P.M.; Formal Analysis, P.C., F.P., V.C., M.S. and G.P.; Investigation, G.P. and F.P.; Resources, P.C.; Software, P.C. and G.P.; Data Curation, G.P.; Writing_-Original Draft Preparation, P.M., G.P. and A.S.; Writing-Review \& Editing, A.S., P.M., P.C., G.P., F.P., V.C. and M.S.; Visualization, G.P., V.C., P.C., F.P; Supervision, A.S.; Project Administration, A.S.; Funding Acquisition, A.S.

Funding: This work was financially supported by “Geo4P” project (EnerGea, CoSviG and Regional Government of Tuscany) and University of Pisa, grant to A. Sbrana. 
Acknowledgments: L. Paci is acknowledged for the technical support during the starting phase of the project. L. Torsello and D. Bonciani are acknowledged for discussion and support during the activity of Geo4P project. Acque SpA and the Civil Engineer division of the Regional Government of Tuscany are acknowledged for sharing their water well data base. The authors are grateful to two anonymous reviewers for their constructive comments and suggestions that helped to improve the quality of the manuscript

Conflicts of Interest: The authors declare no conflict of interest.

\section{Abbreviations}

The following abbreviations are used in this manuscript:

2D Two-dimensional

3D Three-dimensional

a.s.l Above Sea Level

bgl Below Ground Level

BHE Borehole Heat Exchanger

CDU Coastal Dune Unit

CU Clay Unit

CSU Clay and Sands Unit

DTM Digital Terrain Model

EED Earth Energy Designer

EPSG European Petroleum Survey Group

GeoDH Geothermal District Heating systems

GFU Gravel Fans Unit

GHP Geothermal Heat Pump

GIS Geographic Information System

GRS Geodetic Reference System

G.POT Geothermal POTential method

IDW Inverse Distance Weighted interpolation

IFD Integral Finite Difference

RAC Recent Alluvial Cover

SGU Sands and Gravels Unit

SGU-1 Sands and Gravels upper Unit

SGU-2 Sands and Gravels lower Unit

TOUGH Transport of Unsaturated Groundwater and Heat

EOS Equation of State

UTM Universal Transverse of Mercator, cartographic projection

WGS World Geodetic System

\section{References}

1. De la Cruz-Lovera, C.; Perea-Moreno, A.J.; de la Cruz-Fernández, J.L.; Alvarez-Bermejo, J.A.; ManzanoAgugliaro, F. Worldwide Research on Energy Efficiency and Sustainability in Public Buildings. Sustainability 2017, 9, 1294. [CrossRef]

2. Pérez-Lombard, L.; Ortiz, J.; Pout, C. A review on buildings energy consumption information. Energy Build. 2008, 40, 394-398. [CrossRef]

3. EU. Directive 2010/31/EU of the European Parliament and of the Council of 19 May 2010 on the Energy Performance of Buildings. Available online: http:/ / eur-lex.europa.eu/legal-content/en/TXT/?uri=CELEX (accessed on 2 June 2018).

4. Harvey, C.; Beardsmore, G.; Moeck, I.; Rüter, H. Geothermal Exploration: Global Strategies and Applications; IGA Service GmbH: Bochum, Germany, 2016.

5. Chesnaux, R.; Lambert, M.; Fillastre, U.; Walter, J.; Hay, M.; Rouleau, A.; Daigneault, R.; Germaneau, D.; Moisan, A. Building a geodatabase for mapping hydrogeological features and 3D modeling of groundwater systems: Application to the Saguenay-Lac-St-Jean Region, Canada. Comput. Geosci. 2001, 37, 1870-1882. [CrossRef] 
6. Gogu, R.; Carabin, G.; Hallet, V.; Peters, V.; Dassargues, A. GIS-based hydrogeological databases and groundwater modeling. Hydrogeol. J. 2001, 9, 555-569. [CrossRef]

7. Kaufmann, O.; Martin, T. 3D geological modeling from boreholes, cross-sections and geological maps, application over former natural gas storages in coal mines. Comput. Geosci. 2008, 34, 278-290. [CrossRef]

8. Noorollahi, Y.; Itoi, R.; Fujii, H.; Tanaka, T. GIS integration model for geothermal exploration and well siting. Geothermics 2008, 37, 107-131. [CrossRef]

9. Schiel, K.; Baume, O.; Caruso, G.; Leopold, U. GIS-based modelling of shallow geothermal energy potential for $\mathrm{CO}_{2}$ emission mitigation in urban areas. Renew. Energy 2016, 86, 1023-1036. [CrossRef]

10. Ondreka, J.; Rusgen, M.I.; Stober, I.; Czurda, K. GIS-supported mapping of shallow geothermal potential of representative areas in south-western Germany_Possibilities and limitations. Renew. Energy 2007, 32, 2186-2200. [CrossRef]

11. Akar, S.; Atalay, O.; Kuyumcu, O.C.; Solaroglu, U.Z.D.; Colpan, B.; Arzuman, S. 3D subsurface modeling of Gumuscoy Geothermal Area, Aydin, Turkey. Geotherm. Resour. Counc. Trans. 2011, 35, 669-676.

12. Alkaraz, S.; Lane, R.; Spragg, K.; Milicich, S.; Sepulveda, F.; Bignall, G. 3D Geological Modelling Using New Leapfrog Geothermal Software. In Proceedings of the 36th Workshop on Geothermal Reservoir Engineering, Stanford University, Stanford, CA, USA, 31 January 31-2 February 2011.

13. Alkaraz, S.; Chamberfort, I.; Pearson, R.; Cantwell, A. An Integrated Approach to 3-D Modelling to Better Understand Geothermal Reservoirs. In Proceedings of the World Geothermal Congress, Melbourne, Australia, 19-25 April 2015; pp. 1-7.

14. Pearson, S.C.P.; Alcaraz, S.A.; White, P.A.; Tschritter, C. Improved visualization of reservoir simulations: Geological and fluid flow modeling of the Tauranga low-enthalpy geothermal system, New Zealand. Geotherm. Resour. Counc. Trans. 2012, 36, 1293-1297.

15. Fulignati, P.; Marianelli, P.; Sbrana, A.; Ciani, V. 3D geothermal modelling of the Mount Amiata hydrothermal system in Italy. Energies 2014, 7, 7434-7553. [CrossRef]

16. Bellani, S.; Grassi, S.; Squarci, P. Geothermal Characteristics of the Pisa Plain, Italy. In Proceedings of the World Geothermal Congress, Florence, Italy, 18-31 May 1995; Volume 2, pp. 1305-1308.

17. Feng, G.; Xu, T.; Gherardi, F.; Jiang, Z.; Bellani, S. Geothermal assessment of the Pisa plain, Italy: Coupled thermal and hydraulic modeling. Renew. Energy 2017, 111, 416-427. [CrossRef]

18. Gunnarsson, N. 3D Modeling in Petrel of Geological $\mathrm{CO}_{2}$ Storage Site. Master's Thesis, Uppsala University, Uppsala, Sweden, 2011.

19. Pruess, K.; Oldenburg, C.; Moridis, G. TOUGH2 User's Guide, Version 2.0. Report LBNL-43134; Lawrence Livermore Laboratory: Berkeley, CA, USA, 1999; 198p.

20. Narasimhan, T.N.; Witherspoon, P.A. An integrated finite difference method for analyzing fluid flow in porous media. Water Resour. Res. 1976, 12, 57-64. [CrossRef]

21. Audigane, P.; Chiaberge, C.; Mathurin, F.; Lions, J.; Picot-Colbeaux, G. A workflow for handling heterogeneous 3D models with the TOUGH2 family of codes: Application to numerical modeling of $\mathrm{CO}_{2}$ geological storage. Comput. Geosci. 2011, 37, 610-620. [CrossRef]

22. Shepard, D. A Two-Dimensional Interpolation Function for Irregularly-Spaced Data. In Proceedings of the 1968 ACM National Conference, New York, NY, USA, 27-29 August 1968; pp. 517-524.

23. Balke, K.-D. Das Grundwasser als Energieträger. Brennstoff-Warme-Kraft 1977, 29, 191-194.

24. Muffler, P.; Cataldi, R. Methods for regional assessment of geothermal resources. Geothermics 1978, 7, 53-89. [CrossRef]

25. Pascucci, V.; Fontanesi, G.; Merlini, S.; Martini, I.P. Neogene Tuscan Shelf-Western Tuscany extension: Evidences of the early post-compressional deposits (Tyrrhenian Sea-Northern Apennines, Italy). Ofioliti 2001, 26, 187-196. [CrossRef]

26. Sarti, G.; Rossi, V.; Giacomelli, S. The upper Pleistocene “Isola di Coltano sands" (Arno coastal plain, Tuscany Italy): Review of stratigraphic data and tectonic implications for the southern margin of the Viareggio basin. Atti Soc. Tosc. Sci. Nat. Mem. Pisa Italy Serie A 2015, 122, 75-84.

27. Mariani, M.; Prato, R. I bacini neogenici costieri del margine tirrenico: Approccio sismico-stratigrafico. Mem. Soc. Geol. Ital. 1988, 41, 519-531. (In Italian)

28. Trevisan, L.; Tongiorgi, E. Le Acque del Sottosuolo della Regione Pisana. "La Provincia Pisana"; Amministrazione Provinciale: Pisa, Italy, 1953; pp. 3-8. (In Italian) 
29. Dini, I. La Prima Falda Artesiana in Sabbia della Zona di Pisa; Comune e Provincia di Pisa: Pisa, Italy, 1976. (In Italian)

30. Tongiorgi, M.; Rau, A.; Martini, I.P. Sedimentology of early-alpine, fluvio-marine, clastic deposits (Verrucano, Triassic) in the Monti Pisani (Italy). Sediment. Geol. 1997, 17, 311-332. [CrossRef]

31. Fancelli, R. Tentativo di Ricostruzione Dell'andamento della Falda Artesiana tra i-30 ed i-50 m di Profondità nel Sottosuolo di Pisa e Dintorni; Rapporto CNR; Istituto Internazionale Ricerche Geotermiche: Pisa, Italy, 1984. (In Italian)

32. Fancelli, R. Alcune Notizie sui Sedimenti Attraversati da Perforazioni per Ricerche D'acqua e Sulla Distribuzione Spaziale nel Sottosuolo Pisano delle Falde Acquifere; Rapporto CNR; Istituto Internazionale Ricerche Geotermiche: Pisa, Italy, 1984. (In Italian)

33. Baldacci, F.; Bellini, L.; Raggi, G. Le risorse idriche sotterranee della pianura pisana. Atti Soc. Tosc. Sci. Nat. Mem. Pisa Italy Serie A 1994, 101, 241-322. (In Italian)

34. Rossi, S.; Spandre, R. Caratteristiche idrochimiche della I falda artesiana in sabbia nei dintorni della città di Pisa. Acque sotterr. Fasc. 1994, 43, 51-58. (In Italian)

35. Aguzzi, M.; Amorosi, A.; Sarti, G. Stratigraphic architecture of late quaternary deposits in the lower Arno plain (Tuscany, Italy). Geol. Romana 2005, 38, 1-10.

36. Aguzzi, M.; Amorosi, A.; Castorina, F.; Ricci Lucchi, M.; Sarti, G.; Vaiani, C. Stratigraphic architecture and aquifer systems in the eastern Valdarno Basin, Tuscany. Geoacta 2006, 5, 39-60.

37. Aguzzi, M.; Amorosi, A.; Colalongo, M.L.; Ricci Lucchi, M.; Rossi, V.; Sarti, G.; Vaiani, S.C. Late Quaternary climatic evolution of the Arno coastal plain (Western Tuscany, Italy) from subsurface data. Sediment. Geol. 2007, 202, 211-229. [CrossRef]

38. Grassi, S.; Cortecci, G. Hydrogeology and geochemistry of the multi-layered confined aquifer of the Pisa plain (Tuscany-central Italy). Appl. Geochem. 2005, 20, 41-54. [CrossRef]

39. Amorosi, A.; Lucchi, M.R.; Rossi, V.; Sarti, G. Climate change signature of small-scale parasequences from late glacial-Holocene transgressive deposits of the Arno valley fill. Paleogeogr. Paleoclimatol. Palaeoecol. 2009, 273, 142-152. [CrossRef]

40. Sarti, G.; Rossi, V.; Amorosi, A. Influence of Holocene stratigraphic architecture on ground surface settlements: A case study from City of Pisa (Tuscany, Italy). Sediment. Geol. 2012, 281, 75-87. [CrossRef]

41. Bonham-Carter, G.F. Geographic Information Systems for Geoscientists: Modeling with GIS; Pergamon Press: Oxford, UK, 1994; 398p.

42. Carratori, L.; Ceccarelli Lemut, M.L.; Frattarelli Fischer, L.; Garzella, G.; Greco, G.; Grifoni Cremonesi, R.; Mazzanti, R.; Morelli, P.; Nencini, C.; Pasquinucci, M.; et al. Carta degli elementi naturalistici e storici della Pianura di Pisa e dei rilievi contermini, scala 1:50.000. In La Pianura di Pisa e i Rilievi Contermini la Natura e la Storia; Mazzanti, R., Ed.; Memorie della Società Geografica Italiana L: Rome, Italy, 1994; 491p. (In Italian)

43. Belgiorno, M.; Marianelli, P.; Pasquini, G.; Sbrana, A. A contribution to the study of a Pisa alluvial plain sector for low-temperature geothermal assessment. Atti Soc. Tosc. Sci. Nat. Mem. Pisa Italy 2016, 123, 17-23. [CrossRef]

44. Sbrana, A.; Pasquini, G.; Marianelli, P.; Bonciani, D.; Torsello, L. Geo4P-Geothermal Pilot Project Pisan Plain: Quantitative assessment of very low, low and medium temperature shallow geothermal resources. In Proceedings of the European Geothermal Congress, Technology and Best practice-Exploration and Planning, Strasbourg, France, 19-24 September 2016.

45. Hinze, W.J.; Aiken, C.; Brozena, J.; Coakley, B.; Dater, D.; Flanagan, G.; Forsberg, R.; Hildenbrand, T.; Keller, G.R.; Kellogg, J.; et al. New standards for reducing gravity data: The North America gravity database. Geophysics 2005, 70, J25-J32. [CrossRef]

46. Moritz, H. Geodetic Reference System 1980. Bull. Géod. 1980, 54, 395-405. [CrossRef]

47. Banerjee, B.; Das Gupta, S.P. Gravitational attraction of a rectangular parallelepiped. Geophysics 1977, 42, 1053-1055. [CrossRef]

48. Bott, M.H.P. The use of rapid digital computing methods for direct gravity interpretation of sedimentary basins. Geophys. J. Int. 1960, 3, 63-67. [CrossRef]

49. Tuscany Region Website. Available online: http://www.regione.toscana.it/-/geoscopio (accessed on 14 May 2018).

50. Hydrogeological Sector, Tuscany Region. Available online: http://www.sir.toscana.it (accessed on 14 May 2018). 
51. Zhu, K.; Blum, P.; Ferguson, G.; Balke, K.-D.; Bayer, P. The geothermal potential of urban heat islands. Environ. Res. Lett. 2010, 5, 044002. [CrossRef]

52. Hurter, S.; Huenges, E.; Clauser, C.; Haenel, R. (Eds.) Atlas of Geothermal Resources in Europe; European Commission Office for Official Publications of the European Communities: Brussels, Belgium, 2002; 93p.

53. Gazzetta Ufficiale della Repubblica Italiana, D.P.R. 142/93, Allegato A. Available online: http:// efficienzaenergetica.acs.enea.it/doc/dpr412-93.pdf (accessed on 14 May 2018). (In Italian)

54. VDI. VDI 4640 Thermal Use of the Underground. Blatt 1: Fundamentals, Approvals, Environmental Aspects; VDI: Düsseldorf, Germany, 2010.

55. Casasso, A.; Sethi, R. G.POT: A quantitative method for the assessment and mapping of the shallow geothermal potential. Energy 2016, 106, 765-773. [CrossRef]

(c) 2018 by the authors. Licensee MDPI, Basel, Switzerland. This article is an open access article distributed under the terms and conditions of the Creative Commons Attribution (CC BY) license (http:// creativecommons.org/licenses/by/4.0/). 